\title{
Foraminifera and algal biostratigraphy of the Albian- Cenomanian deposits in north of Shiraz, Zagros Basin
}

\author{
Shams Pegah ${ }^{1}$, Maghfouri Moghaddam Iraj ${ }^{* 2}$., Majidifard Mahmoudreza ${ }^{3}$, \\ Parvaneh Nejad Shirazi Mahnaz ${ }^{4}$ \\ ${ }^{1}$ Phd student of Lorestan University, Khorram Abad, Islamic Republic of Iran \\ ${ }^{2}$ Department of Geology, Faculty of Science, Lorestan University, \\ Khorram Abad, Islamic Republic of Iran \\ ${ }^{3}$ Geological survey of Iran, Tehran, Islamic Republic of Iran \\ ${ }^{4}$ Department of Geology, Payam-e- Noor University, Islamic Republic of Iran \\ *Corresponding author, irajmmms@yahoo.co.uk
}

Tel: 00989126188032

\begin{abstract}
Carbonate Albian- Cenomanian successions include the most significant hydrocarbon source rocks in the Zagros Basin. These successions, named the Kazhdumi Formation. Three stratigraphic sections in detail were analyzed and a biostratigraphic zonation of the Albian- Cenomanian rocks is proposed. On the basis of the recognized benthic foraminifera and algal association seven biozone were determined:

Mesorbitolina subconcava/ Hemicycllammina sigali Assemblage zone, Mesorbitolina aperta Taxon Range Zone, Dasycladacea Assemblage Zone, O.(Mesorbitolina) texana Assemblage Zone, Dissocladella deserta Taxon Range Zone, Trinocladus tripolitanus Taxon Range Zone, Mesorbitolina texana partial range zone,Mesorbitolina subconcava range zone, Conicorbitolina onica Taxon range zone.
\end{abstract}

Keywords: Biostratigraphy, Albian, Cenomanian, Foraminifera, Algae. Shiraz

\section{Introduction}

The Albian- Cenomanian deposits of Zagros basin deposited during a relative sea level rise (Ghazban, 2008) and act as a regional source of hydrocarbon (Bordenave, 2002). It was a part of the SW passive margin of the NeoTethys Ocean and the northeastern edge of the Arabian Plate (Ziegler, 2001). Kent et al. described the Kazhdumi Formation for the first time, in an unpublished report in 1950. The formation is named after Kazhdumi Castel in the Tang-e- Gurguda, $10 \mathrm{~km}$ north of Gachsaran.

According to James and Wynd (1965), the Kazhdumi Formation divided into two lateral facies, deep facies (type section) and shallow facies (Figure 1). Deposits of the shallow facies of Kazhdumi Formation are full of fossil fauna such as foraminifers (Bordenave, 2002). The shallow facies was spread in the Fars Zone, and contained shallow limestone. This paper presents the results of the microfacies and microstratigraphical study, based on the benthic foraminifera and algaal content of samples collected in the three sections along the Fars Zone Basin.

\section{Methods and study area}

Three sections of the Kazhdumi Formation were measured bed by bed, and sampled in three areas (Kuh Gadvan, 222; Naqsh rustam, 259.79; Kuh Rahmat, $247.27 \mathrm{~m}$ in thick). The stratigraphic sections under study are located northeast of Shiraz, which is the Interior Fars Zone (Fig2.), with geographic coordinates of: Kuh Gadvan 52 $55^{\prime}$

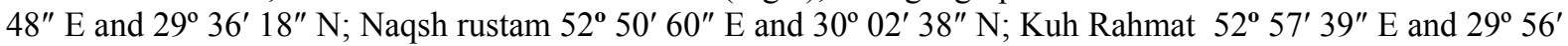
33.3" N (Fig. 1). More than 220 samples from Kazhdumi Formation were studied. All rock samples are housed in the Department of Geology, Lorestan University. Samples were taken from the carbonate and marly layers almost every meter, according to facies variation. Thin sections were provided for the analysis of benthic foraminifera and algae. 


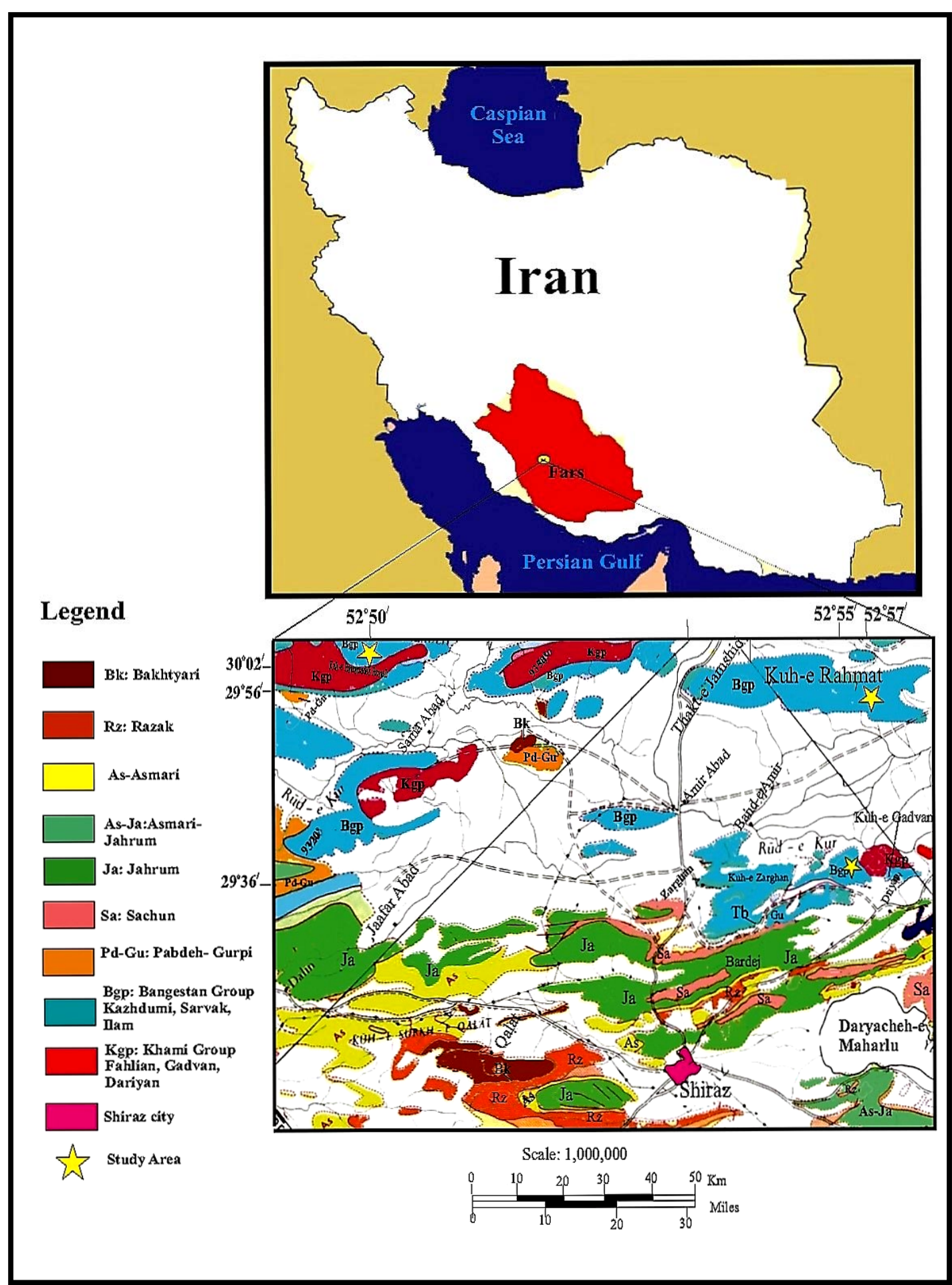

Fig. 1: Location map of the studied area in the Zagros region southwest of Iran (Naghshe-rostam section, Kuhe Rahmat section and Kuhe Gadvan section) (adapted from Geological and Expolartion division, Tehran 1969) 
The fauna association, particularly the foraminifera, was used for the biostratigraphical interpretation, since they are excellent bio-indicators for age dating, as well as the paleoenvironmental interpretation. Larger benthic foraminifera developed complicated internal structures, which can be identified when they are randomly thin sectioned. Beavington- Penny and Racey (2004) showed that because of rapid diversification of foraminifera, these organisms can provide complete and detailed evidence for biostratigraphic analysis of the shelf limestone. During the Aptian- Cenomanian, the benthic foraminifer assemblages in carbonate environments of Tethyan realm were dominated by orbitolinids (Simmons et al. 2000, Schroeder et al. 2010) and therefore, we used the orbitolinids biozonation in order to determine the Kazhdumi Formation age.

Based on the sedimentary sequence, magmatism, metameorphism, structural setting and intensity of deformation, Heydari et al, (2003) subdivided the Iranian Plateau into eight continental fragments, including Zagros, Sanandaj- Syrjan, Urumieh- Dokhtar, Central Iran, Alborz, Kopeh-Dagh, Lut, and Makran

The Zagros is subdivided into different structural zones, including Interior Fars, Coastal Fars and Izeh (Sherkati and Letozey, 2004). The study area is located in the Interior Fars. The Kazhdumi Formation was described for the first time by Kent in an unpublished report in 1950. Prior to its formal definition, the rocks of the Kazhdumi Formation were designated as the Ebad Formation (Motei, 1993).The formation is named after Kazhdumi Castel in the Tang-e- Gurguda, $10 \mathrm{~km}$ north of Gachsaran. In the study area, the Kazhdumi Formation essentially contained a gray medium to thick limestone and gray to yellow marly limestones. Basal contact of Kazhdumi Formation with underlying Daryan Formation is associated with a zone of iron oxide, suggesting either a shallowing or a possible diastem. The upper contact showed a gradational transition to the basal of Sarvak Formation (Figure2, 3, 4). 


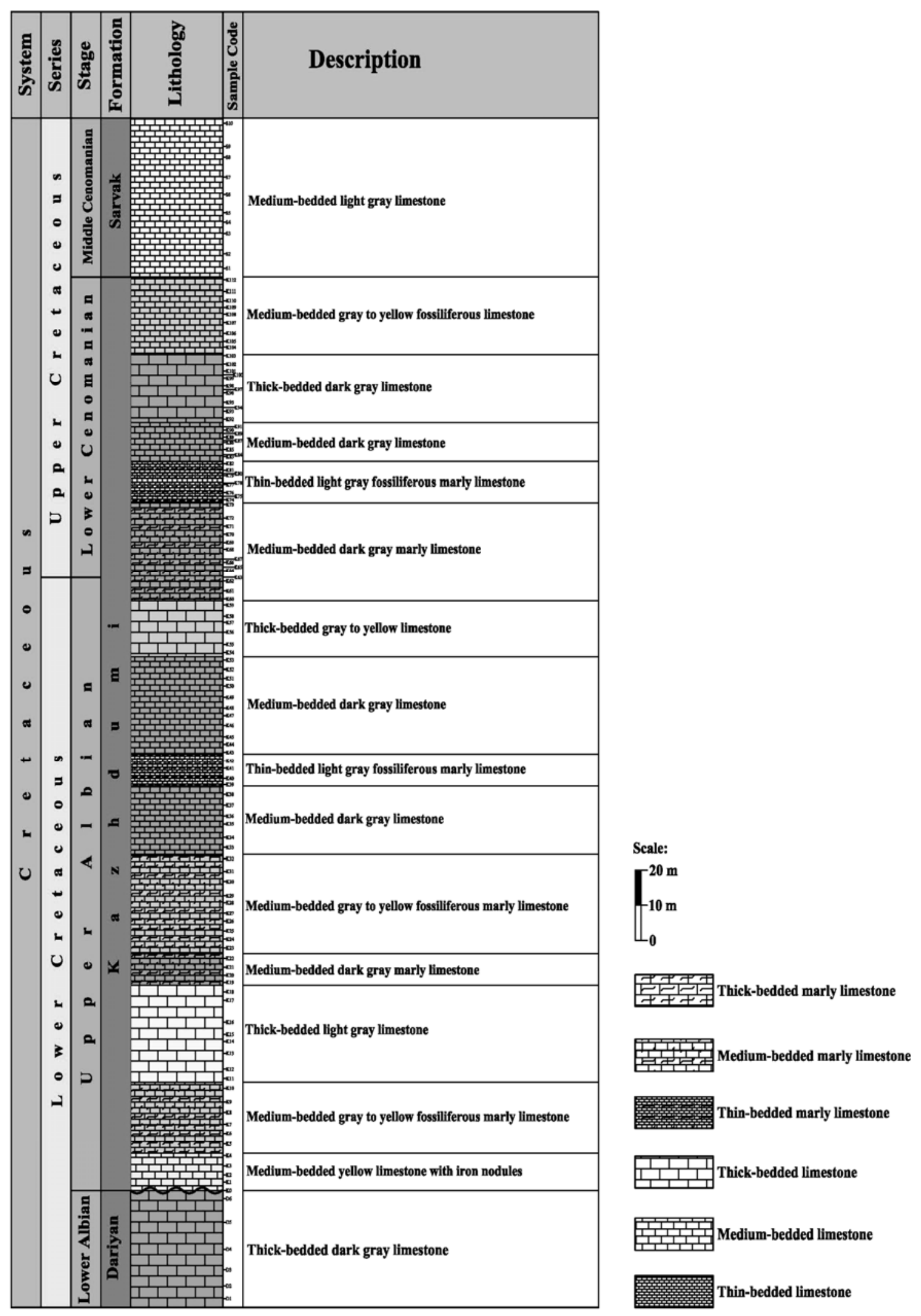

Figure 2: Lithostratigraphic column of the Kazhdumi Formation at Kuh-e-Naghsh-e Rostam section 


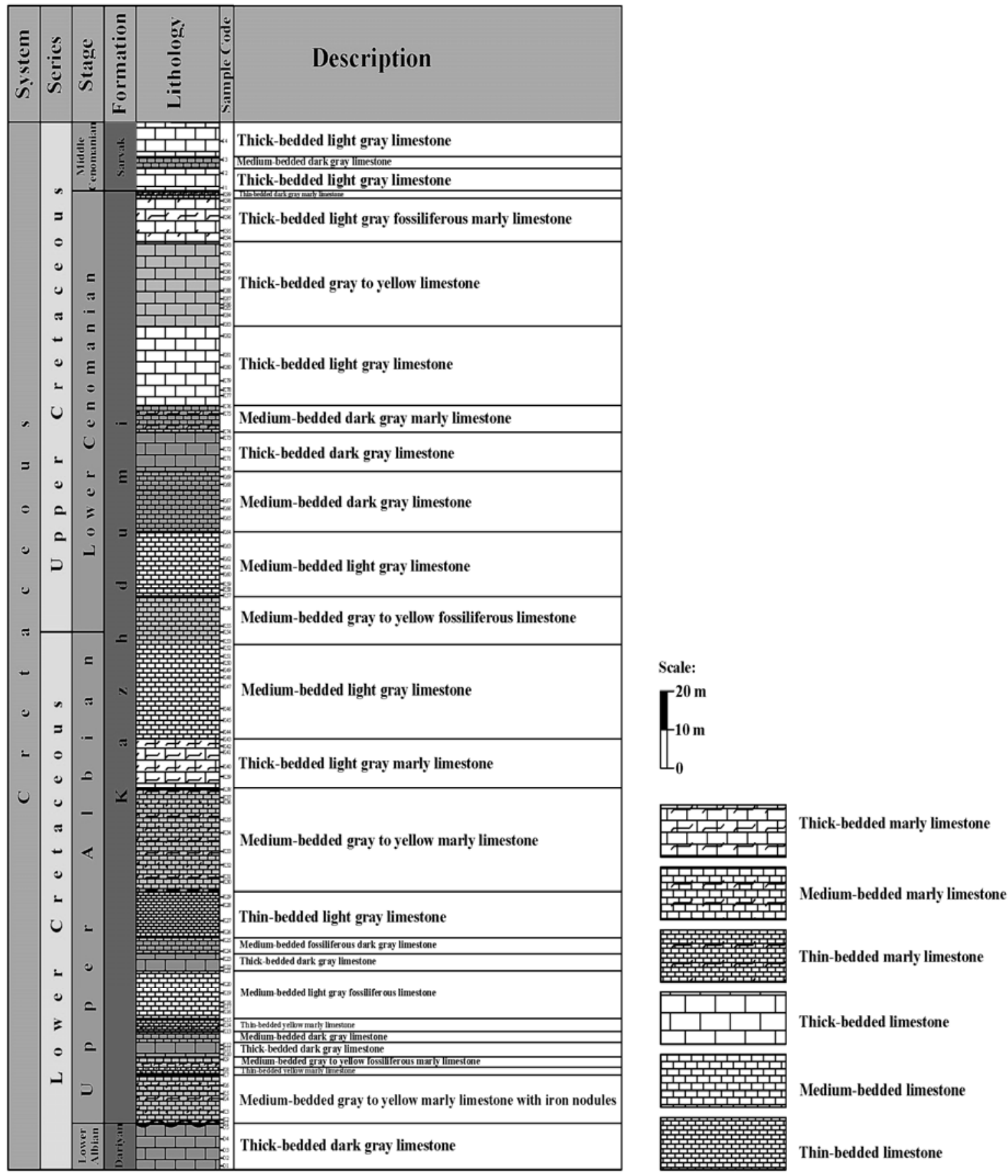

Figure 3: Lithostratigraphic column of the Kazhdumi Formation at Kuh-e-Rahmat section 


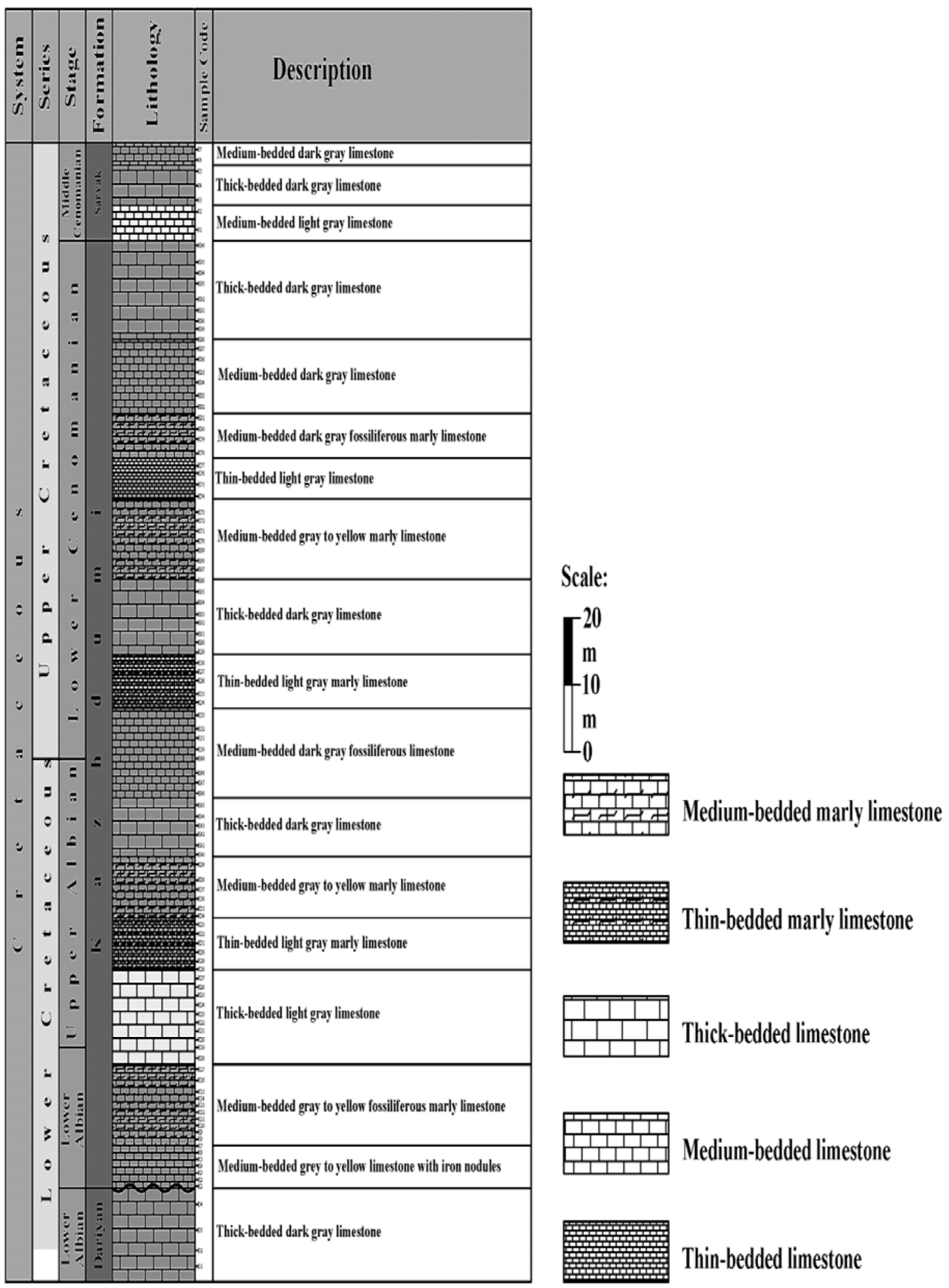

Figure 4: Lithostratigraphic column of the Kazhdumi Formation at Kuh-e-Gadvan section

\section{Evolution of Orbitalina}

Cherchi and Schroeder (2004) propose four evolutionary approaches for orbitolina:

1. Eopalorbitolina pertenuis - Palorbitolina

lenticularis (Early Barremian - Early Late Aptian) 


\section{2 .Praeorbitolina cormyi - Mesorbitolina aperta}

(Early Aptian - Early Cenomanian)

3 .Orbitolina sefini - Orbitolina concave (Late

Albian - Early Cenomanian)

4. Conicorbitolina moulladei- Conicorbitolina

conica (Late Albian - Middle Cenomanian)

In the evolutionary trend of Cherchi and Schroeder (2004), the genus Mesorbitolina is derived from the evolution of the genus Praeorbitolina. In this evolutionary process, the defective embryonic fetal aptient of the Praeorbitolina cormyi species has become more complex over time, ultimately in species. Mesorbitolina aperta evolves (Fig. 6).

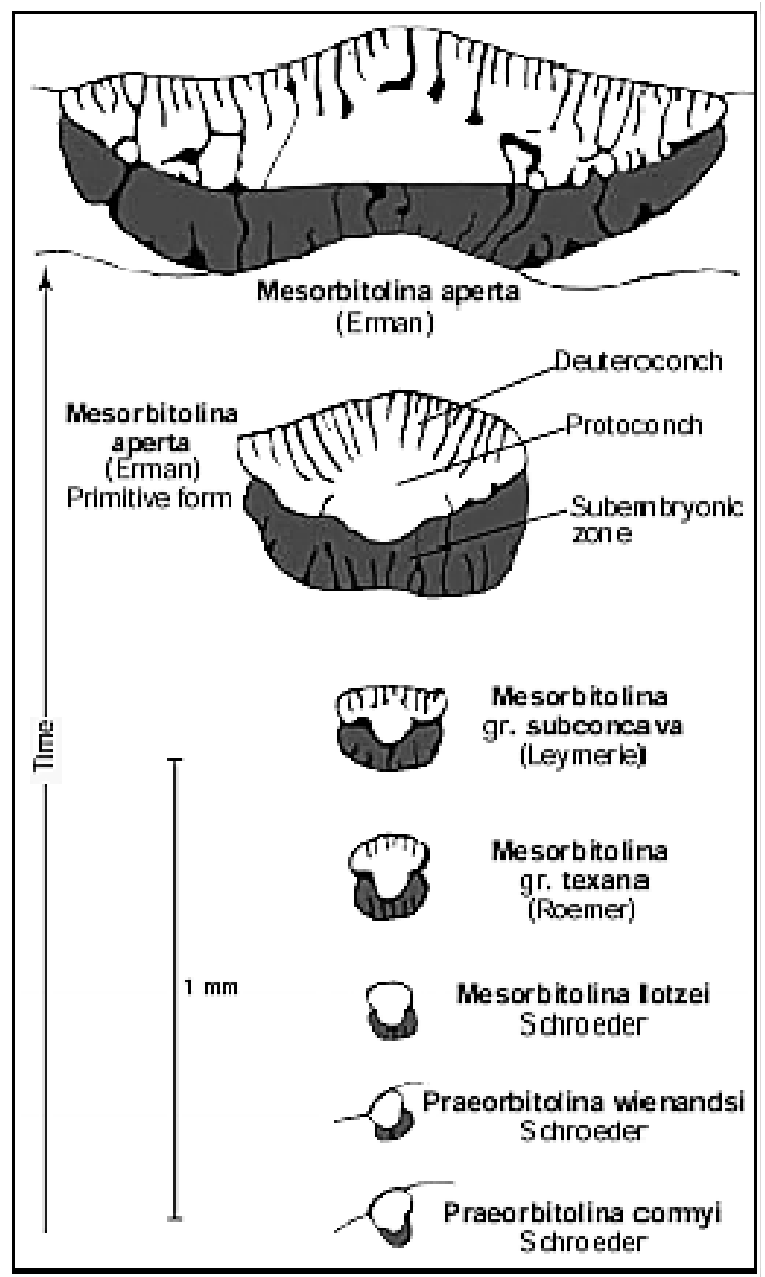

Fig6; Evolution of the embryonic Praeorbitolina cormyi - Mesorbitolina aperta Cherchi \& Schroeder, 2004

In the following figure, the evolution of the embryonic system of the orbitolina identified in three sections of Naghshe-Rostam, Kuhe- Rahmat and Kuhe-Ghadvan (Figure 7)

Evolutionary evolution of identified orbitolina can be part of the evolutionary course of Mesorbitolina parvaConicorbitolina conica, according to Hoffeker (1963) and Cherchi and Schroeder (2004), which is introduced in this study. 


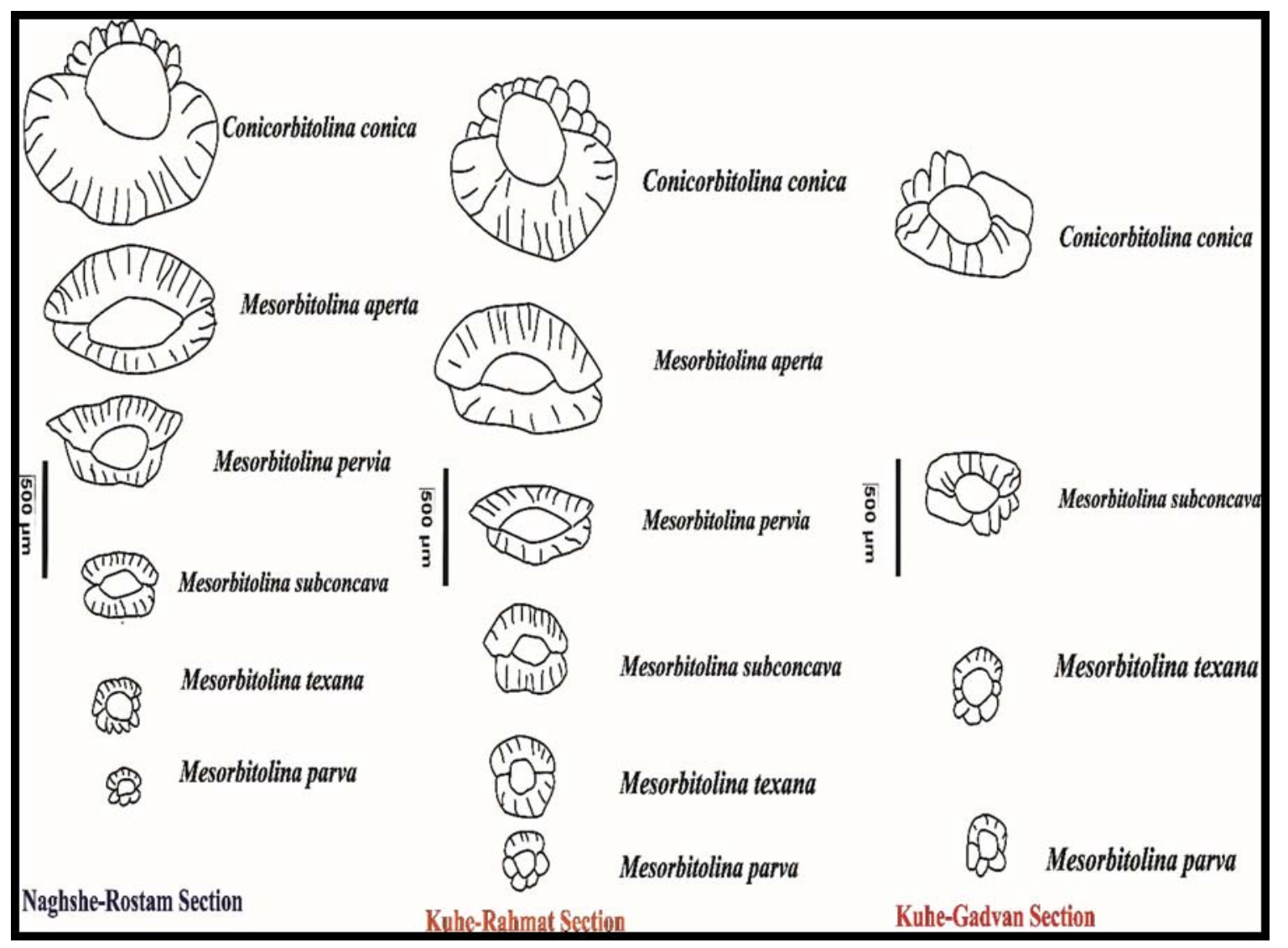

Fig 7; Evolutionary process of embryonic of orbitolina in three sections of Nghshe-Rostam, Kuhe- Rahmat and Kuhe-Gadvan

As can be seen in the figure, a series of evolutionary changes are observed in the studied species, the most important of which is as follows:

Increasing the size of the protoconch: The size of the protoconch increases with time as follows:

Nghshe-Rostam section: M.parva(0.07mm) M. texana (0.08-0.09mm), M.subconcava (0.14-0.16mm), M. pervia (0.13-0.17mm),M. aperta $(0.23 \mathrm{~mm})$, C. Conica $(0.18-0.24 \mathrm{~mm})$.

Kuhe- Rahmat section:M.parva(0.05mm) M. texana (0.06-0.07 mm), M.subconcava (0.11-0.012mm), M. pervia $(0.13 \mathrm{~mm}), M$. aperta $(0.15-0.18 \mathrm{~mm})$, C. Conica $(0.16-0.21 \mathrm{~mm})$,

Kuhe-Gadvan section: M.parva(0.05 mm) M. texana $(0.08 \mathrm{~mm})$, M.subconcava $(0.12 \mathrm{~mm})$, C. Conica (0.16$0.20 \mathrm{~mm})$.

Increasing the size of the embryonic: with time, the size of the embryonic also increases:

Nghshe-Rostam section: M.parva(0.10-0.12 mm) M. texana (0.14-0.15 mm), M.subconcava $(0.19-0.23 \mathrm{~mm})$, M. pervia (0.2-0.24mm), M. aperta (0.21-0.27 mm), C. Conica (0.29-0.36mm).

Kuhe- Rahmat section: M.parva $(0.11 \mathrm{~mm})$ M. texana $(0.14-0.17 \mathrm{~mm})$, M.subconcava $(0.18-0.23 \mathrm{~mm}), M$. pervia (0.22-0.23mm), M. aperta (0.22-0.26 mm), C. Conica $(0.23-0.33 \mathrm{~mm})$,

Kuhe-Gadvan section: M.parva(0.12 mm) ,M. texana (0.13-0.16 mm), M.subconcava (0.17-0.21 mm), C. Conica (0.16-0.29mm).

Increase in the number of divisions of the deuteroconch The number of divorced divisions in the evolution of species increases.

Nghshe-Rostam section : M.parva(4-5) M. texana (6-7), M.subconcava (9-12), M. pervia (14), M. aperta (1316), C. Conica (14-18),

Kuhe- Rahmat section: M.parva(4) M. texana (7), M.subconcava (10-11), M. pervia (12), M. aperta (14), C. Conica (14-15)

Kuhe-Gadvan section: M.parva(4) ,M. texana (7), M.subconcava (8-11), C. Conica (6-12).

Increasing the number of sub-ambryonic region division;

Nghshe-Rostam section : M.parva(3) M. texana (5-6), M.subconcava (7), M. pervia (8-9), M. aperta (8-10), C. Conica (18-20), 
Kuhe- Rahmat section: M.parva(4) M. texana (5-6), M.subconcava (7-8), M. pervia (8), M. aperta (8-10), C. Conica (16-17),

Kuhe-Gadvan section: M.parva(3) ,M. texana (3-5), M.subconcava (6), C. Conica (8-14).

Deformation in the sub-ambryonic region: sub-ambryonic region in M. texana, M. parva and to some extent in M. subconcava is rectangular and trapezoidal in C. Conica

Protoconch change: the protoconch shape changes in the evolutionary curriculum so that

The protococonch in M. parva and M. texana are semi-spherical and in M. subconcava the protoconch is wider and the protoconch width is larger than its height, and in C. Conica, the protoconch is half-shaped The sphere is flat and the upper surface is convex.

\section{Biostratigraphy}

The sedimentary deposits of the study area yielded abundant larger benthic foraminifera. Therefore, biostratigraphic zonation is based on these organisms. They show a widespread distribution, high diversity and abundance in the studied sections, and thus are important for the biostratigraphic subdivision. Benthic foraminifera reflect shallow environments and high-stress conditions, as indicated by generally low diversity, dwarfing and sporadic presence of index species (Figure9). However, several intervals of the studied AlbianCenomanian succession show more diverse and abundant assemblages, and permit a good resolution when all biostratigraphic data are combined. Based on the concepts of Velić (2007), Schroeder et al. (2010) and Gradstein et al. (2012), the following 7 biozones were defined (Figure 6 to 8).

\section{Mesorbitolina texana Partial Range Zone}

This biozone spans the total range of Mesorbitolina texana ( Velić, 2007).

Description: This biozone spans a long early to Middle Albian stratigraphic interval. The following, such as Mesorbitolina texana, Orbitolina sp, Monteseciella arabica, Salpingoporella dinarica.

Correlation: The benthonic foraminifera assemblage described coincides with the O. (Mesorbitolina) texana Biozone of South Pamyrides after Ghanem et al. (2012) and the same zone in the Adriatic Platform (Loeblich and Tappan, 1988; Velić, 2007). Mid Cretaceous orbitolinid (Foraminiferida) record from the islands of Cres and Los inj (Croatia), and its regional stratigraphic correlation (Husinec1, Velic, 2000).

Age and Occurrence: The Mesorbitolina texana comprises the Middle to late Albian ((Husinec1, Velic, 2000; Velić, 2007; Ghanem et al., 2012). The The Mesorbitolina texana Biozone is evident in the base of formation $31.54 \mathrm{~m}$ in Kuhe Gadvan section.

\section{Late Albian}

\section{Mesorbitolina subconcava/ Hemicycllammina sigali Assemblage Zone}

Diagnosis: This biozone spans the total range of Mesorbitolina subconcava/ Hemicycllammina sigali (Velić, 2007; Schroeder et al, 2010; Ghanem et al., 2012).

Description: This biozone spans a long Middle- Late Albian stratigraphic interval. However, the lower part of the Lower Albian is missing. The following late Albian index taxa, such as Mesorbitolina texana, Orbitolina $c f$ parva, Favusella washitensis, Orbitolina sp, Conicorbitolina conica, Monteseciella Arabica, Salpingoporella sp.

Correlation: The benthonic foraminifera assemblage described coincides with the Mesorbitolina subconcava/ Hemicycllammina sigali Biozone of South Pamyrides after Ghanem et al. (2012), and the same zone in the Adriatic Platform (Velić, 2007).

Age and Occurrence: The M. subconcava Zone comprises the Middle to late Albian (Simmons et al., 2000; Velić, 2007; Ghanem et al., 2012). The M. subconcava Biozone is evident in the base of formation to $174.4 \mathrm{~m}$ in the Naghshe-rostam section. This biozone is equal to the Dasycladacea Assemblage Zone (Wynd, 1965).

\section{Mesorbitolina subconcava Range Zone}

Diagnosis: This biozone spans the total range of Mesorbitolina subconcava (Velić, 2007; Schroeder et al, 2010; Ghanem et al., 2012).

Description: This biozone spans a long Middle- Late Albian stratigraphic interval. The following late Albian index taxa, such as Mesorbitolina texana, Salpingoporella dinarica, Orbitolina parva, Orbitolina sp., Marsonella trochus.

Correlation: The benthonic foraminifera assemblage described coincides with the Mesorbitolina subconcava Biozone of South Pamyrides after Ghanem et al. (2012) and the same zone in the Adriatic Platform (Velić, 2007). 
Age and Occurrence: The M. subconcava Zone comprises the Middle to late Albian (Simmons et al., 2000; Velić, 2007; Ghanem et al., 2012). The M. subconcava Biozone is evident in the 31.54 of formation to $96.5 \mathrm{~m}$ in Kuhe Gadvan section.

\section{O. (Mesorbitolina) texana Assemblage Zone}

Diagnosis: This biozone spans the total range of O. (Mesorbitolina) texana (Velic' et al., 2007; Gus 'ic' \& Jelaska, 1993).

Description: This biozone spans a long Middle- Late Albian stratigraphic interval. However, the lower part of the Lower Albian is missing (compare Sequence ApCR1). The following late Albian index taxa, such as Favusella washitensis, Orbitolina sp, Conicorbitolina conica, Monteseciella Arabica, Marsonella trochus, Salpingoporella sp.

Correlation: The benthonic foraminifera assemblage described coincides with the O. (Mesorbitolina) texana Biozone of South Pamyrides after Ghanem et al. (2012) and the same zone in the Adriatic Platform (Velić, 2007), Mid Cretaceous orbitolinid (Foraminiferida)record from the islands of Cres and Los inj(Croatia) and its regional stratigraphic correlation (Husinec1, Velic, 2000).

Age and Occurrence: The $O$. (Mesorbitolina) texana comprises the Middle to late Albian ((Husinec1, Velic, 2000; Velić, 2007; Ghanem et al., 2012). The The O. (Mesorbitolina) texana Biozone is evident in $1.5 \mathrm{~m}$ of formation to125.92m in Kuh-e Rahmat section. This biozone equal to Dissocladella deserta (Wynd, 1965).

\section{Early Cenomanian}

\section{Conicorbitoina concava Taxon Range Zone}

Diagnosis: This biozone spans the total range of Conicorbitoina concava (Velić, 2007).

Description: This biozone spans a long early Cenomanian stratigraphic. The following late Albian index taxa, such as Conicorbitolina conica, Orbitolina concava, Biserial lituolid, Cuneolina pavonia, Dicyclina schlumbergeri.

Correlation: The benthonic foraminifera assemblage described coincides with the Conicorbitoina concava Biozone of Biostratigraphy and carbon-isotope stratigraphy of the uppermost Aptian to Upper Cenomanian strata of the South Palmyrides, Syria Hussam Ghanem, Mikhail Mouty and Jochen Kuss (2012). The Late Albian to Early Cenomanian succession at Mont Risou near Rosans (Drome, SE France).

Age and Occurrence: The Conicorbitoina concava Taxon Range Zone comprises the early Cenomanian (1998; Velić, 2007; Ghanem et al., 2012). The Mesorbitolina aperta Taxon Range Zone Biozone is evident in 174.4m to $252.79 \mathrm{~m}$ in Kuhe Naghsh-e Rostam section. This biozone equal to Dasycladacea Assemblage Zone (Wynd, 1965.

\section{Conicorbitolina cuvilleri / Conicorbitolina conica Assemblage Zone}

Diagnosis: This biozone spans the total range of Conicorbitolina cuvilleri / Conicorbitolina conica (Velić, 2007).

Description: This biozone spans a long early Cenomanian stratigraphic. The following late Albian index taxa, such as Conicorbitolina conica, Orbitolina concava, Biserial lituolid.

Correlation: The benthonic foraminifera assemblage described coincides with the Conicorbitolina cuvilleri / Conicorbitolina conica Biozone of Biostratigraphy and carbon-isotope stratigraphy of the uppermost Aptian to Upper Cenomanian strata of the South Palmyrides, Syria Hussam Ghanem, Mikhail Mouty and Jochen Kuss (2012). The Late Albian to Early Cenomanian succession at Mont Risou near Rosans (Drome, SE France),

Microfossil assemblages and the Cenomanian-Turonian. Mixed siliciclastic and carbonate platform of AlbianCenomanian age from the Iberian Basin, Spain.

Age and Occurrence: The Conicorbitolina cuvilleri / Conicorbitolina conica Biozone comprises the early Cenomanian (Velić, 2007; Ghanem et al., 2012). The Conicorbitolina cuvilleri / Conicorbitolina conica Biozone Biozone is evident in $125.92 \mathrm{~m}$ to $242.27 \mathrm{~m}$ in Kuhe Rahmat section. This biozone equal to Trinocladus tripolitanus (Wynd, 1965).

\section{Conicorbitolina conica Taxon Range Zone}

Diagnosis: This biozone spans the total range of Conicorbitolina conica (Velić, 2007).

Description: This biozone spans a long early Cenomanian stratigraphic. The following late Albian index taxa, such as Conicorbitolina conica, Orbitolina sp., chrysidalina sp.

Correlation: The benthonic foraminifera assemblage described coincides with the Conicorbitolina conica Biozone of Biostratigraphy and carbon-isotope stratigraphy of the uppermost Aptian to Upper Cenomanian strata of the South Palmyrides, Syria Hussam Ghanem, Mikhail Mouty and Jochen Kuss (2012). The Late Albian to Early Cenomanian succession at Mont Risou near Rosans (Drome, SE France). Microfossil 
assemblages and the Cenomanian-Turonian. Mixed siliciclastic and carbonate platform of Albian-Cenomanian age from the Aberian Basin, Spain.

Age and Occurrence: Conicorbitolina conica Biozone comprises the early Cenomanian (Velić, 2007; Ghanem et al., 2012). The Conicorbitolina conica Biozone Biozone is evident in $96.5 \mathrm{~m}$ to $212.88 \mathrm{~m}$ in Kuhe Gadvan section.

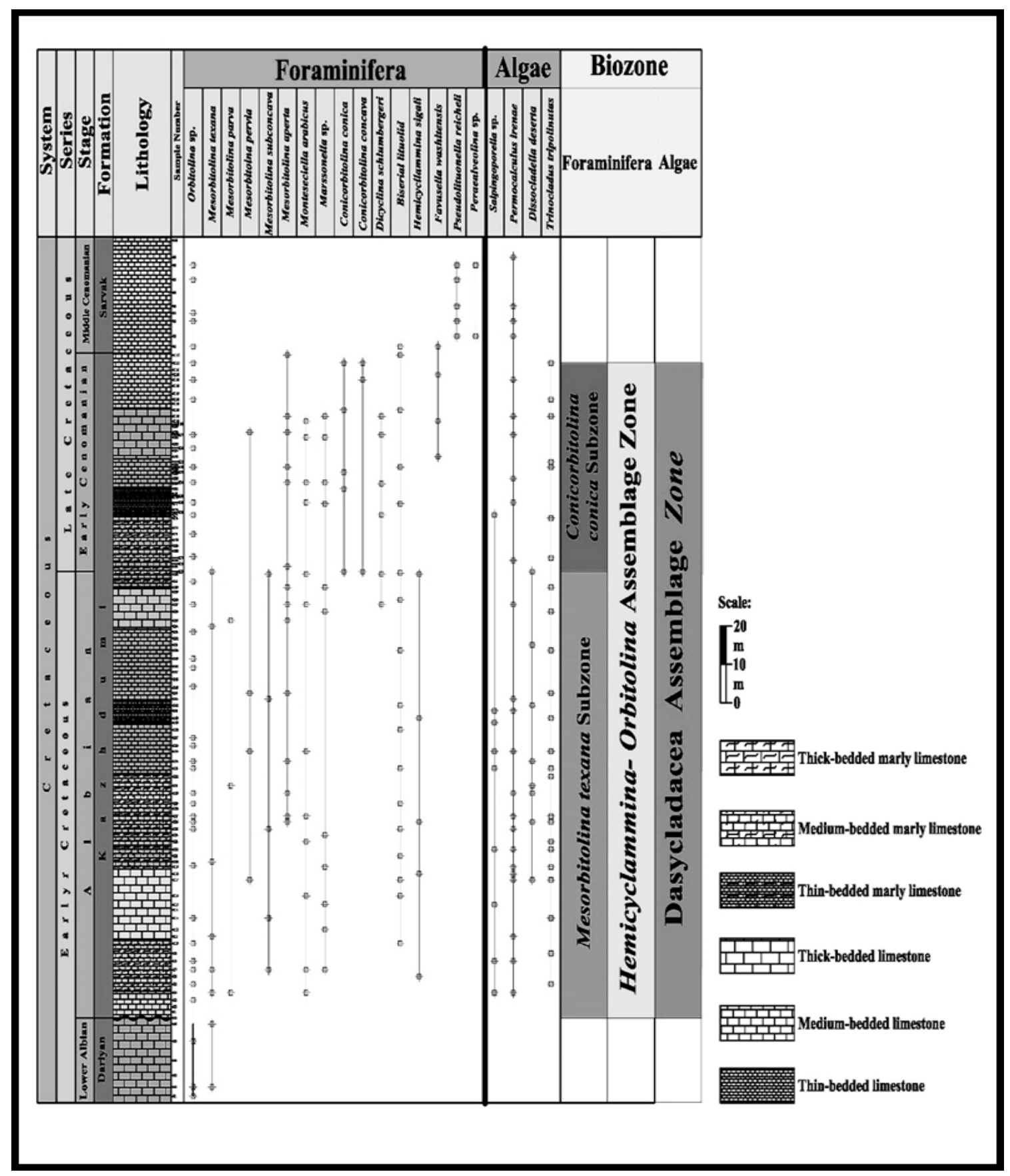

Figure 6: Biostratigraphic column of the Kazhdumi Formation at Kuh-e-Naghsh-e Rostam 


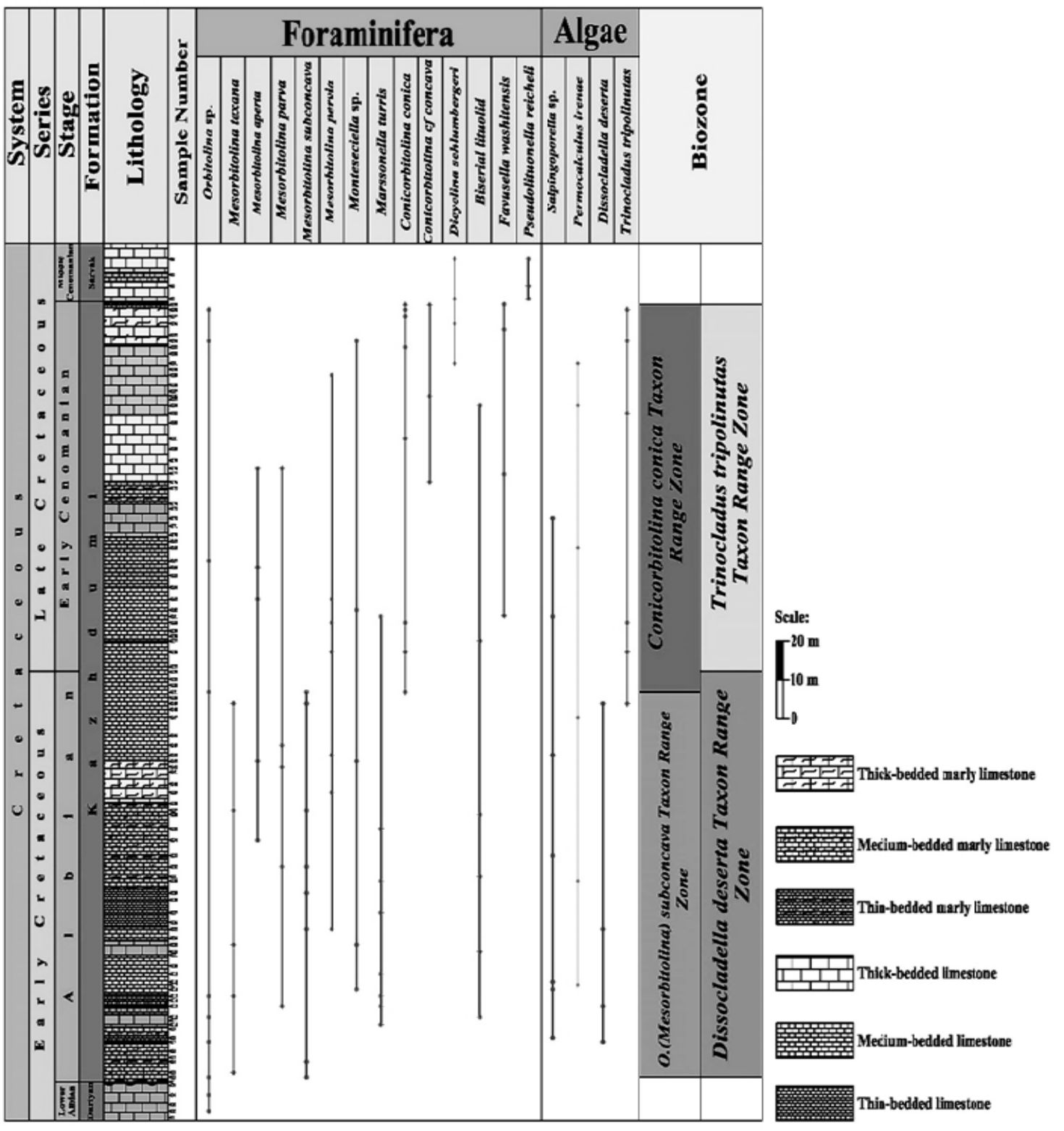

Figure 7: Biostratigraphic column of the Kazhdumi Formation at Kuh-e-Rahmat section 


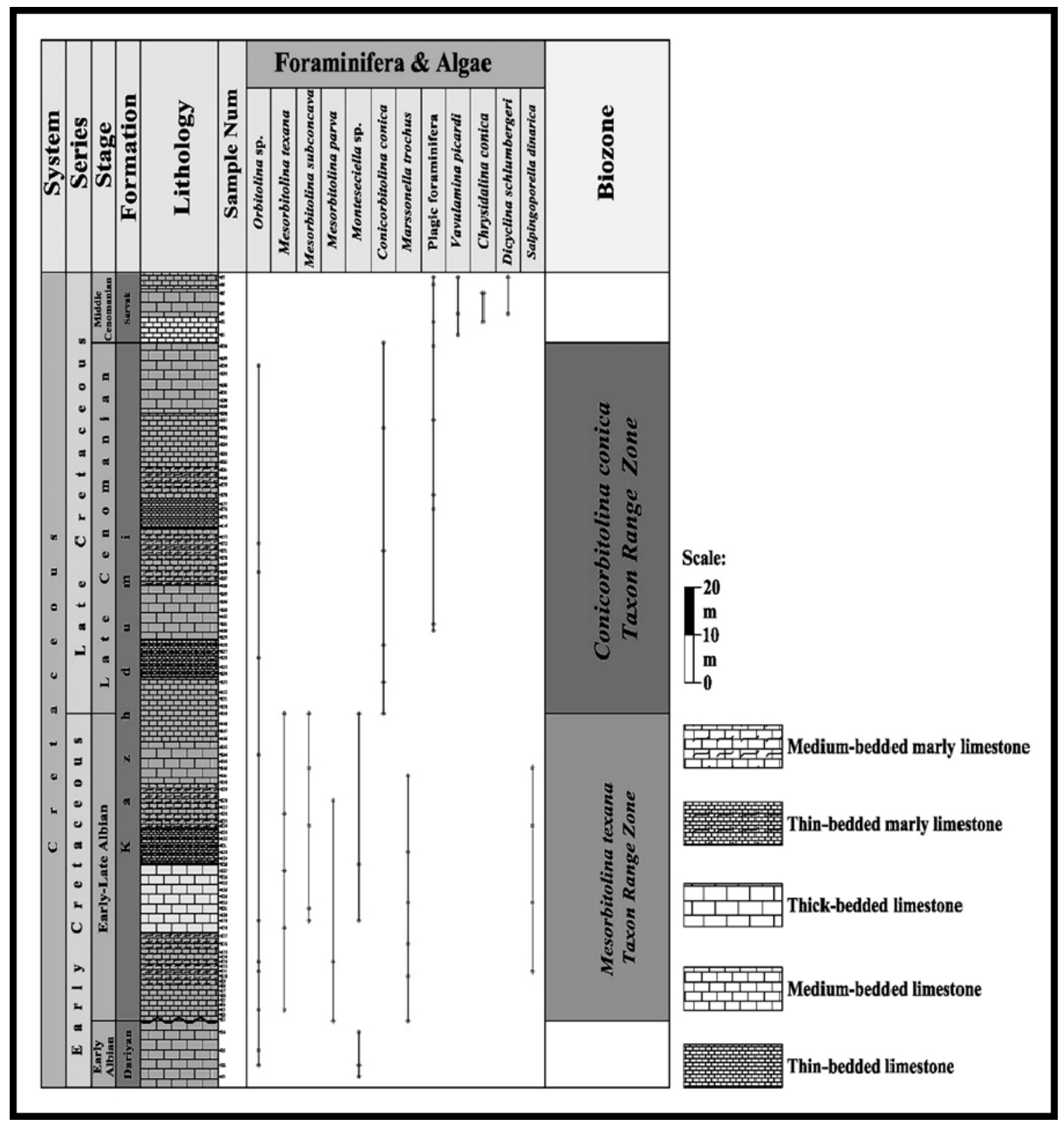

Figure 8: Biostratigraphic column of the Kazhdumi Formation at Kuh-e-Gadvan 


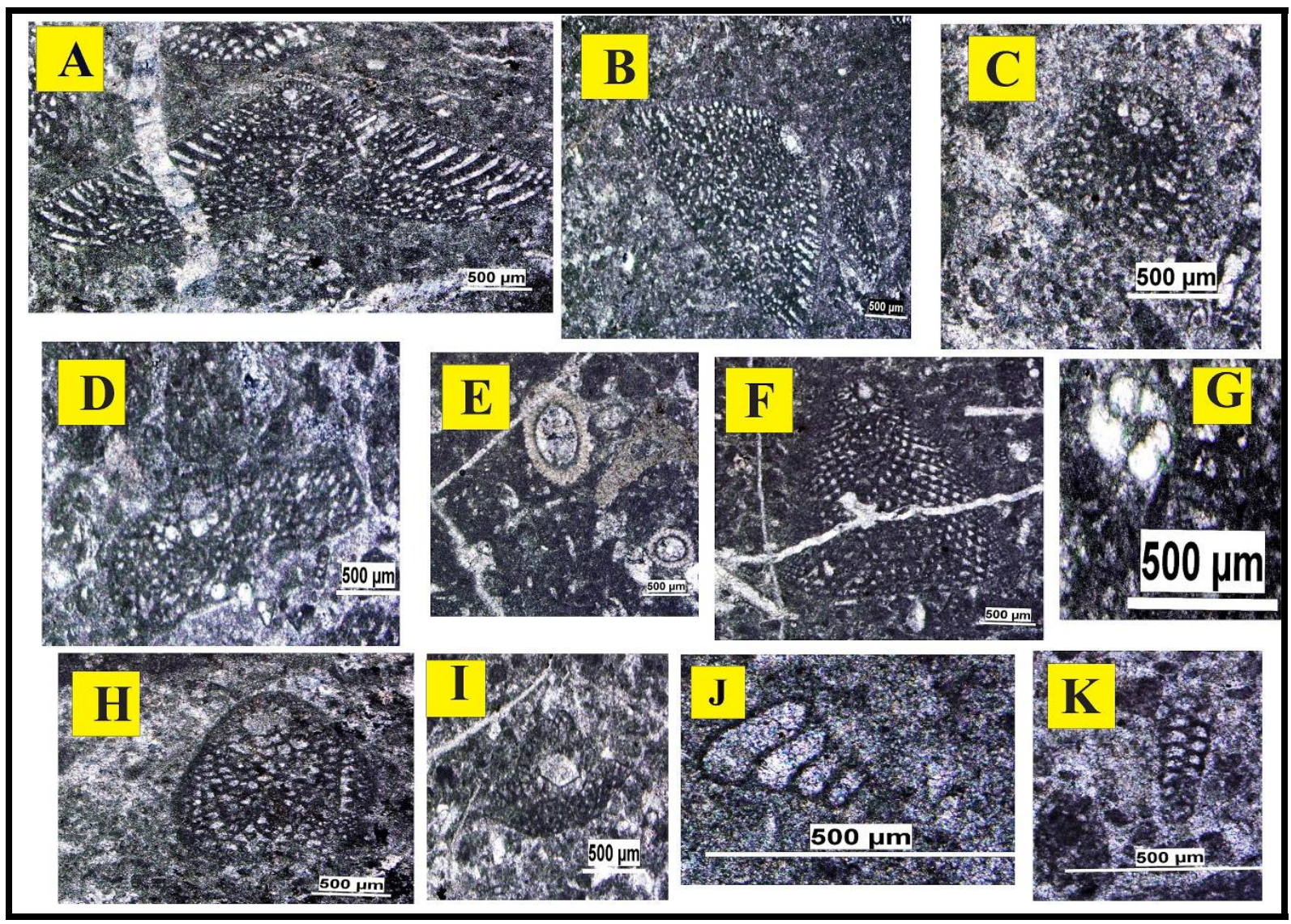

Figure9: Benthic foraminifers of the Kazhdumi Formation; A) Mesorbitolina subconcava, sample no.K3; B) Mesorbitolina texana, sample no.K37; C) Mesorbitolina parva, sample no.K4, D) Mesorbitolina pervia, sample no. K19, E) Salpingoporella dinarica, sample no.K11; F) Iraqia sp., K48; H) Orbitolina (Conicorbitolina) conica,K53; I) Orbitolina (Conicorbitolina) conica, sample no. 65; G) Favusella washitensis, sample no.K9; J) Marsonella trochus, sample no.K6; K) Textullaria sp., sample no.K12.

\section{Conclusions}

The Kazhdumi Formation is composed of gray medium to thick limestone and gray to yellow marly limestones in three sections studied. Micropalaeontological and biostratigraphical study of the Kazhdumi Formation led d to establishment of 7 biozones. Mesorbitolina texana Partial range zone; Mesorbitolina subconcava/ Hemicycllammina sigali Assemblage Zone; Mesorbitolina subconcava Range Zone; O. (Mesorbitolina) texana Assemblage Zone; Conicorbitoina concava Taxon Range Zone; Conicorbitolina cuvilleri / Conicorbitolina conica Assemblage Zone; Conicorbitolina conica Taxon Range Zone. Based on the occurrence of large benthic foraminifera and algae associations, the Kazhdumi Formation at the study area is Albian to Early Cenomanian in age.

\section{References}

[1] Beavingtone-Penney SJ. Racey A. (2004). Ecology of extant nummulitids and other larger benthic foraminifera. Applications in Paleoenvironmental analysis: Eaerth-Sci Rev 67(3-4), 219-265.

[2] Bordenave, M.L. \& Burwood, R. (2002). Source rock distribution and maturation in the Zagros orogenic belt, Provenance of the Asmari and Sarvak reservoir oil accumulation. Organic Geochemistry 16, 369-387.

[3] Chatalov, A. (2013). A Triassic homoclinal ramp from the Western Tethyan realm, Western Balkanides, Bulgaria: Integrated insight with special emphasis on the Anisian outer to inner ramp facies transition. Palaeogeography, Palaeoclimatology,Palaeoecology 386, $34-58$.

[4] Ghanem, H., M. Mouty and J. Kuss (2012). Biostratigraphy and carbon-isotope stratigraphy of the uppermost Aptian to Late Cenomanian strata of the South Palmyrides, Syria. Geoarabia, v. 17, no. 2, p. 155-184.

[5] Ghazban, F., 2007, Petroleum Geology of the Persian Gulf, Tehran university, 707p.

[6] Gradstein, F.M., J.G. Ogg, M. Schmitz and G. Ogg (2012). (Eds.). The Geologic Time Scale 2012. Elsevier, 144.

[7] Heydari E, Hassanzadeh J, Wade WJ, Ghazi AM, (2003). Permian- Triassic boundary interval in the Abadeh section of Iran with implications for mass extinction. Palaeogeogr palaeocl 193: 405-423.

[8] James GA, Wynd JG (1965). Stratigraphic nomenclature of Iranian oil consortium agreement area. AAPG Bull:2182-2245pp.

[9] Kent, P.E., (1950). The Behbahan- Kazerun Survey 1949- 1950 Iooc Report No. 792(Unpub).

[10] Loeblich, A.R., Tappan, J.H., (1988), Foraminiferal Genera and their Classification. Van Nostrand Reinhold. 2 vols. pls. 847. NewYork, $869 \mathrm{p}$.

[11] Motiei H. (1993).Stratigraphy of Zagros, Geol Surv Iran. 346 pp.

[12] Penney S.J. \& Racey, A. (2004). Ecology of extant nummulitids and other larger benthic foraminifera: applications in palaeoenvironmental analysis. Earth-Science Reviews 67, 219-265. 
[13] Schoroeder R., Van Buchem, F., Cherchi A., Baghbani, D., Vincent, B., IMMENHAUSER, A. \& Granier B. (2010). Revised orbitolinid biostratigraphic zonation for the Barremian - Aptian of the eastern Arabian Plate and implications for regional stratigraphic correlations. GeoArabia Special Publication 4, 49-96. SIMMONS, M.D. 1994. Micropalaeontological biozonation of the Kahmah Group (Early Cretaceous), central Oman Mountains, 177-219. SimmonsM.D. (ed.) Micropalaeontology and Hydrocarbon Exploration in the Middle East. Chapman and Hall, London.

[14] Simmons, M.D. (1994). Micropalaeontological biozonation of the Kahmah Group (Early Cretaceous), central Oman Mountains, In SIMMONS, M.D. (ed.) Micropalaeontology andHydrocarbon Exploration in the Middle East. Chapman and Hall, London, 177-219.

[15] Sherkaty S. and Letouzey J. (2004), Variation of structural style and basin evolution in the central Zagros (Izeh zone and Dezful beltl Iran): Marine petrol geol. 21:35- 5 .

[16] Velic', I. (1988). Lower Cretaceous benthic foraminiferal biostratigraphy of the shallow water carbonates of the Dinarides. Revue de Pale'obiologie, Volume Special 2 (Benthos '86), 467-475.

[17] Velic', I. \& Vlahovic', I. 1994. Foraminiferal assemblages in the Cenomanian of the Buzet-Savudrija area (northwestern Istria, Croatia). Geologia Croatica 47, 25-43.

[18] Velić, I. (2007). Stratigraphy and Palaeobiogeography of Mesozoic Benthic Foraminifera of the Karst Dinarides (SEEurope). Geologia Croatica, v. 60, no. 1, p. 1-113.

[19] Zigeler, M.A. (2001). Late Permian to Holocene paleofacies evolution of the Arabian Plate and its hydrocarbon occurrences.GeoArabia 6, 445-504. 